\title{
Cluster Analysis, Association and Path Coefficient Analysis for Seed Yield Improvement in Rapeseed
}

\author{
Tahira*, Muhammad Arshad, Muhammad Ayub Khan and Mubashar Ahmad Khan
}

Oilseeds Research Program, CSI, NARC, Islamabad, Pakitan.

Abstract | The present investigations were carried out to determine the degree of variation among rapeseed hybrids and the best selection criteria for yield enhancement in rapeseed (Brassica napus).For this thirty-six rapeseed hybrids were sown in a RCBD with four repeats at NARC, Islamabad during the cropping season 2014 and 2015. Cluster analysis based on WARD's method showed considerable genetic variation among the hybrids. In the first year, thirty- six Brassica hybrids were grouped into thirteen clusters. Cluster-IV comprised of maximum number of hybrids (six). The clusters mean and standard deviation marked that hybrid in Cluster XI (CRH-80) was short durational and high yielding mainly due to more branches and pods per plant.CRH-35 in cluster-VI was high yielding and has more seeds per pod. Similarly in second year, these thirty-six Brassica hybrids were grouped into ten clusters. Cluster-I consist of seven hybrids. Analysis for mean and standard deviation showed that hybrids in Cluster-VII (Hyola-401) was short durational and produced more number of seeds per pod. Genotypes CRH-84 and CRH-235 grouped in cluster IV produced maximum number of branches and pods per plant. It was observed that hybrids in Cluster-X (CHR-286 and CHR-102) having more pod length were high yielding. Genotypic and phenotypic correlations studies revealed that number of pods per plant had highly significant positive correlation with seed yield. The results of path coefficient analysis indicated that in both years, the direct effects of pod length and number of pods per plant on grain yield were positive and of high magnitude. Finally, it was concluded that the trait pods per plant can be exploited for the improvement of seed yield in rapeseed.

Received | 25 June 2017; Accepted | October 08, 2017, 2016; Published | November 29, 2017

*Correspondence | Tahira, Oilseeds Research Program, CSI, NARC, Islamabad, Pakitan; Email: drtahirawaqas@yahoo.com

Citation | Tahira, M. Arshad, M.A. Khan And M.A. Khan. 2017. Cluster analysis, associationand path coefficient analysis for seed yield improvement in rapeseed. Pakistan Journal of Agricultural Research, 30(4): 315-322.

DOI | http://dx.doi.org/10.17582/journal.pjar/2017/30.4.315.322

Keywords | Rapeseed hybrids, Cluster analysis, Association analysis, Path analysis, Seed yield and yield components

\section{Introduction}

A number of oilseed crops are being grown in Pakistan. Among these rapeseed and mustard crops occupy special importance. It is not only the third most important oil seed crop of the country but also reported as the second most important oilseed crop in the international oilseed market as a source of vegetable oil (Hasan et al., 2006). Pakistan is producing 215.8 thousand tones of rapeseed and mustard from an area of 213.9 thousand hectares December 2017 | Volume 30 | Issue 4 | Page 316 with average yield of $1009 \mathrm{kgha}^{-1}$ (AS, 2014-15). The edible oil consumption was 3.002 million tons of which 0.573 million tons (19\%) came from local resources and 2.429 million tons (81\%) were imported (Anonymous, 2013-14). In addition, canola was grown on an area of about 15,700 hectares with a production of 16,800 tons. These figures showed that the production of edible oil in Pakistan is not sufficient to meet the consumption requirement due to increasing population. Consequently, a huge amount of foreign exchange is spent every year on its 
import.

Shah et al. (2000) said that it is essential to take important actions to improve the yield potential of Brassica. The yield trait is dependent on many other quantitatively inherited traits like seed weight, number of seeds, number of pods etc.According to Tuncturk and Ciftci (2007) it is important to observe the contribution of each of the trait so that more attention can be given only to those traits that show the greatest influence on seed yield. Punitha et al. (2010) stated that cluster analysis is a powerful tool in quantifying the degree of genetic divergence among parents.Importance of genotypic and phenotypic variability, heritability and character association have proved by many scientists (Ali et al., 2002; Lekh et al., 1998) for further genetic improvement. Positive and significant correlations of seed yield with plant height, branches and silique per plant were recorded by Sandhu and Gupta (1996). In Indian mustard positive correlation of seed yield with pods per plant, 1000 seed weight were also reported by Khubli and Pant (1999).

Korkut et al. (1993) described that the simple correlation analysis could not fully give details link among the characters. Therefore, path coefficient analysis is optional to utilize for more and complete determination of impact of independent variable on dependent one. So direct and indirect effects can clearly be understood by path analysis. Many researchers have widely used this analysis to explain the direct and indirect effects of different traits on yield in different crop species.

Marjanovic et al.(2011) reported that according to genetic path-coefficient analysis pods per plant and oil content were the most important components of seed yield per plant as their direct effects on seed yield per plant were $p=0.472$ and $p=0.082$, respectively. Seyedmohammadi (2013) concluded from path analysis that, number of pods per plant had the highest direct effect on grain yield. The current investigations were intended to estimate heritability, association and selection criteria for yield components in rapeseed (Brassica napus).

\section{Materials and Methods}

Trial comprising thirty-six rapeseed hybrids was carried out at experimental area of Oilseeds Research Program, NARC, Islamabad in a RCBD with four repeats. Experiment was sown in two cropping season 2014 and 2015. Three weeks after sowing the distance of 10-15 centimeter between the plants was kept by thinning. Each genotype was planted in four rows of 5 meter length by $30 \mathrm{~cm}$ apart. Fertilizers, $N$ with 90 kgha ${ }^{-1}$ and $\mathrm{P}_{2} \mathrm{O}_{5}$ with $60 \mathrm{kgha}^{-1}$ were applied during seed bed preparation. Irrigation, weed and pest control measures were taken whenever required.

Observations for days to maturity, branches plant ${ }^{-1}$, pod length $(\mathrm{cm})$, number of seeds per pod, number of pods per plant, thousand seed weight (TSW) and seed yield $\mathrm{kgha}^{-1}$ were recorded for each entry and replication. From the mean of the hybrids, Cluster diagram was made by using WARD's method (Sneath and Sokal, 1973).Genotypic and phenotypic coefficients of variability were worked out according to the formula given by Burton (1952). The genotypic and phenotypic correlation coefficients were estimated as calculated by Kwon and Terrie (1964). The path coefficients were obtained according to the method suggested by Dewey and Lu (1959).

Table 1: Analysis of variance of different traits of rapeseed bybrids.

\begin{tabular}{lllllllll} 
SOV & & $\begin{array}{l}\text { Days to } \\
\text { maturity }\end{array}$ & $\begin{array}{l}\text { Branches per } \\
\text { plant }\end{array}$ & Pod length & $\begin{array}{l}\text { Pods per } \\
\text { plant }\end{array}$ & \multicolumn{2}{l}{$\begin{array}{l}\text { Seeds per } \\
\text { pod }\end{array}$} & $\begin{array}{l}\text { Thousand seed seed yield } \\
\text { weight }\end{array}$ \\
Mean & 2014 & 6.643 & 0.502 & 0.795 & 2345.6 & 5.562 & 0.122 & 113636.6 \\
square & 2015 & 4.771 & 0.507 & 0.599 & 1337.29 & 7.807 & 0.099 & 390974.2 \\
F-value & 2014 & $1.861^{* *}$ & $3.092^{* *}$ & $3.004^{* *}$ & $4.844^{* *}$ & $2.379^{* *}$ & $3.553^{* *}$ & $4.038^{* *}$ \\
& 2015 & $1.7^{* *}$ & $1.885^{* *}$ & $2.168^{* *}$ & $3.695^{* *}$ & $2.896^{* *}$ & $3.144^{* *}$ & $17.805^{* *}$ \\
CD1 & 2014 & 2.645 & 0.564 & 0.72 & 30.809 & 2.141 & 0.259 & 234.855 \\
CD1 & 2015 & 2.345 & 0.726 & 0.736 & 26.634 & 2.299 & 0.249 & 207.467 \\
CD2 & 2014 & 3.496 & 0.745 & 0.952 & 40.721 & 2.83 & 0.343 & 310.412 \\
CD2 & 2015 & 3.1 & 0.96 & 0.973 & 35.203 & 3.038 & 0.329 & 274.212
\end{tabular}

**: Significant at 0.01 probability level; *: Significant at 0.05 probability level; NS: Non-significant. 
Results and Discussion

The statistical analysis of data showed significant differences among entries for all the traits recorded (Table 1). The data recorded was also statistically significant for the year. So the data recorded in two years for different traits couldn't be pooled. Cluster analysis, correlation and path coefficient analysis for each year were calculated separately. The results obtained is described as follow.

\section{Cluster analysis}

Cluster analysis is a valuable tool in classifying the material into different groups according to variation present among them. Knowledge about the variation of different genotypes is one of the principles in breeding programs. In present studies The WARD's method is used to group the rapeseed hybrids into different clusters in two seasons as described below.

During 2014: On the basis of WARD's method, thirty- six brassica hybrids were grouped into thirteen clusters (Table 2). Cluster-IV comprised of maximum number of hybrids (six) followed by Cluster I, VIII and $\mathrm{X}$ compromised of four hybrids in each. There were three hybrids in Cluster II, III and XII while Cluster VII, IX and XIII consisted of two hybrids. Cluster V, VI and XI comprised of one hybrid in each cluster (Figure 1). All the clusters were analyzed for mean and standard deviation (Table 3 ) and it was evident from the result that hybrid in Cluster XI (CRH-80) was short durational with more branches and pods per plant and was high yielding. Hybrid CRH-35 in
cluster-VI was high yielding and had more seeds per pod. Khan et al. (2013) reported similar findings in 32 genotypes of $B$.rapa into 6 clusters.

Table 2: Distribution of 36 rapeseed bybrids in 13 clusters during 2014.

$\begin{array}{lll}\text { Cluster } & \begin{array}{l}\text { Number } \\ \text { of hybrids }\end{array} & \text { Names of hybrids } \\ \text { I } & 4 & \begin{array}{l}\text { CRH-176, CRH-196, CRH-19, } \\ \text { CRH-153 }\end{array} \\ \text { II } & 3 & \begin{array}{l}\text { CRH-15, CRH-258, CRH-138 } \\ \text { CRH-77, CRH-33, CRH-150 }\end{array} \\ \text { III } & 3 & \begin{array}{l}\text { CRH-84, CRH-32, CRH-10, CRH- } \\ \text { IV }\end{array} \\ & 6 & \text { 10, CRH-12, CRH-41, CRH-103 } \\ \text { V } & 1 & \text { HYOLA-401 } \\ \text { VI } & 1 & \text { CRH-35 } \\ \text { VII } & 2 & \text { CRH-312, CRH132 } \\ \text { VIII } & 4 & \text { CRH-352, CRH-327, CRH-286, } \\ & & \text { CRH-233 } \\ \text { IX } & 2 & \text { CRH-235, CRH-137 } \\ \text { X } & 4 & \text { CRH-369, CRH-260, CRH-223, } \\ & & \begin{array}{l}\text { CRH-105 } \\ \text { CRH-80 }\end{array} \\ \text { XI } & 1 & \text { CRH-81, CRH-79, CRH-162 } \\ \text { XII } & 3 & \text { CRH-180, CRH-102 } \\ \text { XIII } & 2 & \end{array}$

During 2015: Similarly, during year 2015 these thirtysix brassica hybrids were grouped into ten clusters on the basis of WARD's method (Table 4). Cluster-I consisted of seven hybrids followed by Cluster-VIII which comprised of six clusters and Cluster-VI consisted of five hybrids (Figure 2). There were four hybrids in Cluster-II and three hybrids in Cluster

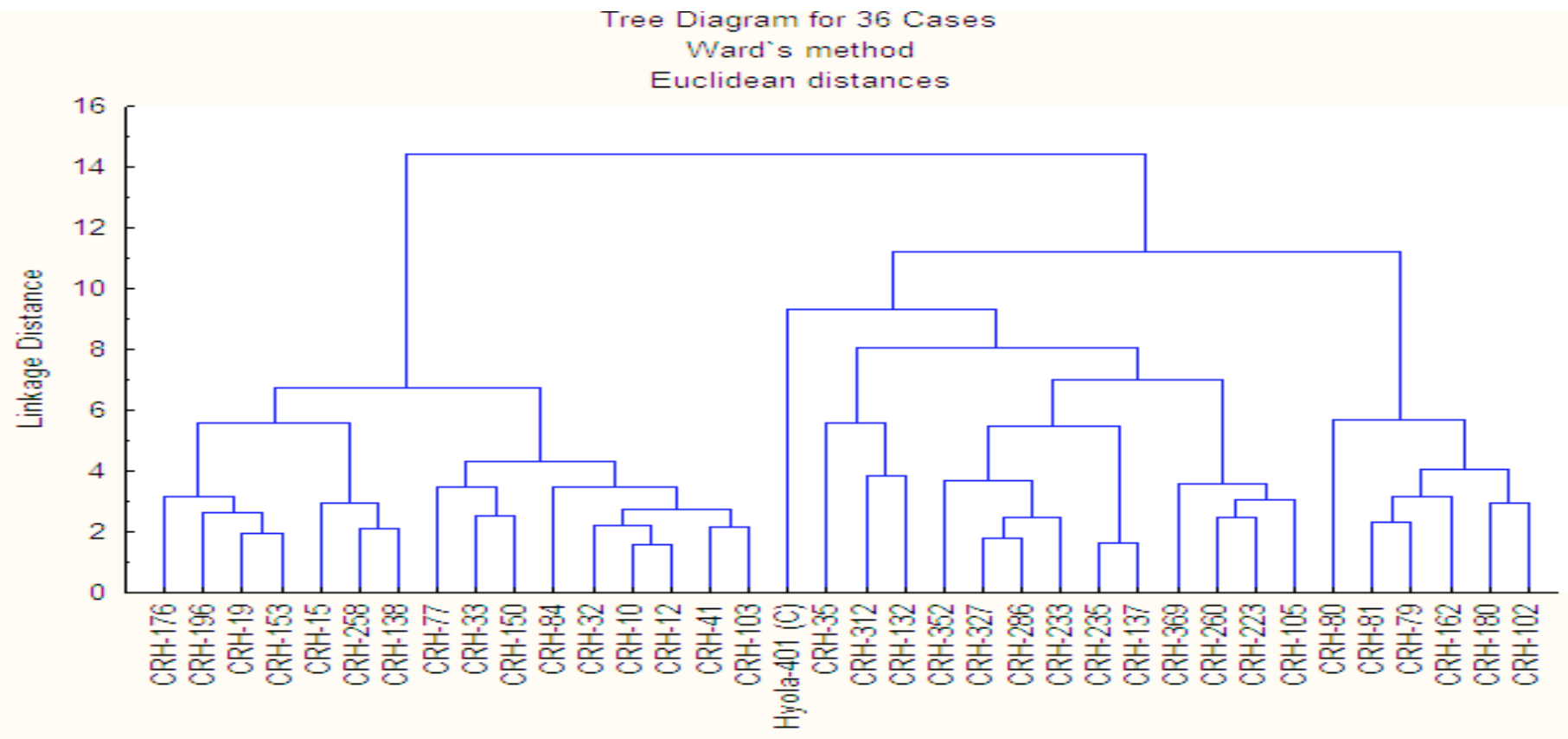

Figure 1: Cluster diagram of 7 traits in 36 rapeseed hybrids in 2014.

December 2017 | Volume 30 | Issue 4 | Page 318 
Table 3: Cluster mean and standard deviation of rapeseed bybrids for seven traits during 2014.

CLI CLII CLIII CLIV CLV CLVI CLVII CLVIII CLIX CLX CLXI CLXII CLXIII

$\begin{array}{lllllllllllllll}\mathrm{DM} & 184.625 & 185.25 & 185.08 & 184.38 & 184.38 & 184.75 & 183.0 & 184.31 & 184.5 & 181.94 & 181 & 184.92 & 184.63 \\ & \pm 0.43 & \pm .43 & \pm 0.76 & \pm 0.9 & \pm 0 & \pm 0 & \pm 1.06 & \pm 0.97 & \pm 0.35 & \pm 0.90 & \pm 0 & \pm 1.04 & \pm 0.88 \\ \mathrm{PL} & 7.14 & 6.9 & 7.72 & 7.3 & 7.60 \pm 0 & 9.0 \pm 0 & 7.3 & 7.28 & 7.24 & 6.82 & 7.40 & 6.78 & 7.49 \\ & \pm 0.10 & \pm 0.25 & \pm 0.19 & \pm 0.13 & & & \pm 0.42 & \pm 0.18 & \pm 0.40 & \pm 0.35 & \pm 0 & \pm 0.09 & \pm 0.03 \\ \mathrm{BP}^{-1} & 6.30 & 6.42 & 6.30 & 6.37 & 6.25 \pm 0 & 6.45 \pm 0 & 6.02 & 6.21 & 6.55 & 6.46 & 7.65 & 6.82 & 6.9 \\ & \pm 0.20 & \pm 0.08 & \pm 0.37 & \pm 0.28 & & & \pm 0.24 & \pm 0.29 & \pm 0.07 & \pm 0.14 & \pm 0 & \pm 0.16 & \pm 0.21 \\ \mathrm{PP}^{-1} & 255.31 & 239.17 & 257.0 & 237.58 & 227.25 & 253.75 & 261.25 & 264.69 & 244.13 & 279.56 & 307.00 & 294.92 & 274.12 \\ & \pm 21.05 & \pm 11.6 & \pm 16.40 & \pm 6.3 & \pm 0 & \pm 0 & \pm 41.72 & \pm 16.88 & \pm 16.88 & \pm 22.24 & \pm 0 & \pm 9.93 & \pm 1.62 \\ \mathrm{SP}^{-1} & 22.48 \pm & 20.80 & 21.40 & 21.62 & 22.65 \pm 0 & 24.5 \pm 0 & 24.98 & 22.20 & 20.90 & 22.22 & 21.85 & 21.88 & 23.1 \\ & 0.85 & \pm 0.88 & \pm 0.78 & \pm 0.74 & & & \pm 0.6 & \pm 0.25 & \pm 0.07 & \pm 1.03 & \pm 0 & \pm 0.27 & \pm 0.92 \\ \text { TSW } & 3.58 \pm .07 & 3.35 \pm & 3.33 & 3.39 & 3.17 \pm 0 & 3.53 \pm 0 & 3.40 \pm 0 & 3.58 & 3.84 & 3.64 & 3.33 & 3.47 & 3.7 \\ & & 0.12 & \pm 0.12 & \pm 0.06 & & & & \pm 0.12 & \pm 0.88 & \pm 0.12 & \pm 0 & \pm 0.06 & \pm 0.16 \\ \text { SY } & 2119.25 & 2277.33 & 2605.42 & 2428.04 & 2562.75 & 2661.5 & 2374.13 & 2415.38 & 2509.13 & 2595.06 & 2618.25 & 2560 & 2500 . \\ & \pm 125 & \pm 58 & \pm 42.3 & \pm 107.3 & \pm 0 & \pm 0 & \pm 192.1 & \pm 53.85 & \pm 27 . & \pm 131.4 & \pm 0 & \pm 193 & \pm 33.94\end{array}$

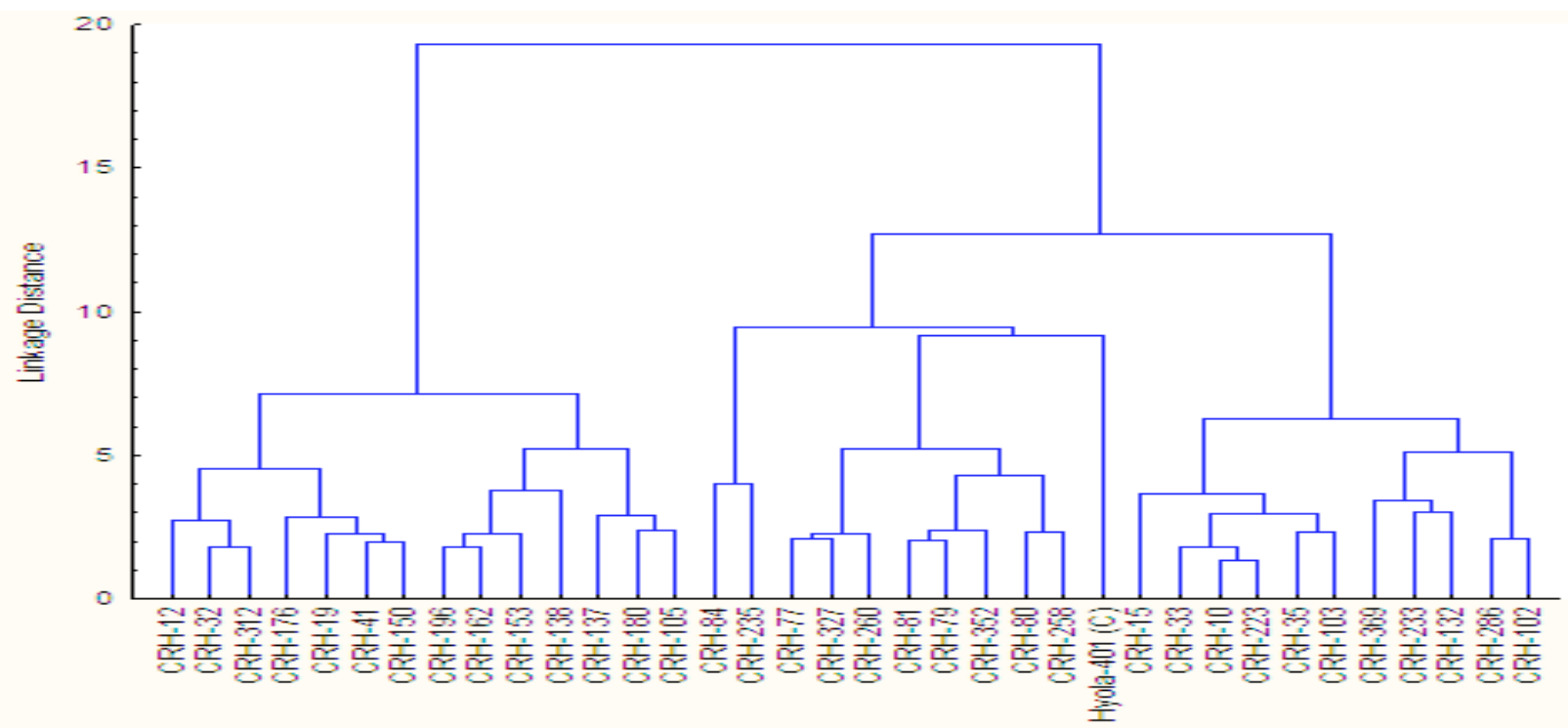

Figure 2: Cluster diagram of 7 traits in 36 rapeseed bybrids in 2015.

Table 4: Distribution of 36 genotypes of rapeseed hybrids in 10 clusters during 2015.

$\begin{array}{lll}\text { Cluster } & \begin{array}{l}\text { Number of } \\ \text { genotypes }\end{array} & \text { Names of genotypes } \\ \text { I } & 7 & \begin{array}{l}\text { CRH-12, CRH-32, CRH-312, } \\ \text { CRH-176, CRH-19, CRH-41, } \\ \text { CRH-150 }\end{array} \\ \text { II } & 4 & \begin{array}{l}\text { CRH-196, CRH-162, CRH-153, } \\ \text { CRH-138 }\end{array} \\ \text { III } & 3 & \begin{array}{l}\text { CRH-137, CRH-180, CRH-105 } \\ \text { CRH-84, CRH-235 }\end{array} \\ \text { IV } & 2 & \text { CRH-77, CRH-327, CRH-260 } \\ \text { V } & 3 & \begin{array}{l}\text { CRH-81, CRH-79, CRH-352, } \\ \text { CRH-80, CRH-258 }\end{array} \\ \text { VI } & 5 & \begin{array}{l}\text { HYOLA 401 } \\ \text { CRH-15, CRH-33, CRH-10, }\end{array} \\ \text { VII } & 1 & \text { CRH-223, CRH-35, CRH-103 } \\ \text { VIII } & 6 & \text { CRH-369, CRH-233, CRH-132 } \\ \text { IX } & 3 & \text { CRH-286, CRH-102 } \\ \text { X } & 2 & \end{array}$

III, $\mathrm{V}$ and IX each. Cluster IV and $\mathrm{X}$ contained two hybrids in each cluster. Cluster-VII comprised of single hybrid. Analysis for mean and standard deviation showed that hybrid in Cluster-VII (Hyola-401) was short duration and produced more number of seed per pod. Similarly the plants of hybrids CRH-84 and CRH-235 grouped in cluster IV produced maximum number of branches and pods per plant.It was observed that hybrids in Cluster- X (CHR-286 and CHR-102) had more pod length and were high yielding (Table 5). Therefore, it was suggested that these hybrids should be exploit under wide environment for better outcome. Mohan and Seetharam (2005) also reported similar clustering pattern, as some clusters were unique having only single genotype. In research conducted by Arshad et al. (2007) there were three clusters among which genotypes in Cluster II with high seed yield, 100 seed weight and oil content percentage 
Table 5: Cluster mean and standard deviation of rapeseed bybrids for seven traits during 2015.

$\begin{array}{lllllllllll} & \text { CL I } & \text { CLII } & \text { CLIII } & \text { CLIV } & \text { CLV } & \text { CLVI } & \text { CLVII } & \text { CLVIII } & \text { CLIX } & \text { CLX } \\ \text { DM } & 182.76 \pm 1.1 & 183.98 & 182.33 & 183.05 & 180.77 & 182.28 & 180 & 182.83 & 183.13 & 183.4 \pm 0.14 \\ & & \pm 0.9 & \pm 0.29 & \pm 0.35 & \pm 0.25 & \pm 0.29 & \pm 0 & \pm 0.41 & \pm 1.26 & \\ \text { PL } & 5.88 \pm 0.17 & 5.83 & 5.92 & 6.49 \pm & 5.99 & 6.2 & 5.88 & 6.7 & 6.45 & 6.93 \pm \\ & & \pm 0.08 & \pm 0.03 & 0.15 & \pm 0.14 & \pm 0.14 & \pm 0 & \pm 0.15 & \pm 0.08 & 0.46 \\ \text { B/P } & 5.84 \pm 0.19 & 5.68 & 5.77 & 6.9 & 5.63 & 5.94 & 6.0 \pm 0 & 5.82 & 5.57 & 6.1 \pm 0 \\ & & \pm 0.19 & \pm 0.12 & \pm 0.28 & \pm 0.23 & \pm 0.11 & & \pm 0.38 & \pm 0.21 & \\ \text { P/P } & 232.14 \pm 8.5 & 213.25 & 211.67 & 267 . & 253.67 & 248.8 & 249 \pm 0 & 230.00 & 232.00 & 255 \pm 5.66 \\ & & \pm 7.04 & \pm 4.73 & \pm 29.7 & \pm 10.69 & \pm 9.01 & & \pm 8.56 & \pm 15.87 & \\ \text { S/P } & 18.29 \pm 0.56 & 19.05 & 18.6 & 20.65 & 19.47 & 20.2 & 21.6 \pm 0 & 21.38 & 21.5 & 21.1 \pm 0.57 \\ & & \pm 1.15 & \pm 1.37 & \pm 0.07 & \pm 0.58 & \pm 0.72 & & \pm 0.18 & \pm 0.7 & \\ \text { TSW } & 3.7 \pm 0.09 & 3.46 & 5.51 & 3.3 & 368 & 3.56 & 3.65 \pm 0 & 3.53 & 3.82 & 3.63 \pm 0.04 \\ & & \pm 0.07 & \pm 0.13 & \pm 0.28 & \pm 0.13 & \pm 0.1 & & \pm 0.12 & \pm 0.02 & \\ \text { SY } & 1888.86 \pm 210 & 1942.75 & 1682.68 & 1736 & 2416 & 2109 & 2373 \pm 0 & 1939.17 & 2256 & 2683.5 \pm 50.2 \\ & & \pm 81 & \pm 132.2 & \pm 326 & \pm 25.1 & \pm 342 & & \pm 120.2 & \pm 217.3\end{array}$

* DM: Days to maturity; $\mathbf{B p}^{-1}$ : Branches per plant; PL: Pod length (cm); PP-1: Pods per plant; SP-1: Seeds per pod; TSW: Thousand Seed Weight (g); SY: Seed Yield $\mathrm{Kg}_{\mathrm{ha}} \mathrm{i}^{-1}$

Table 6: Genotypic and phenotypic correlation among different traits of rapeseed bybrids.

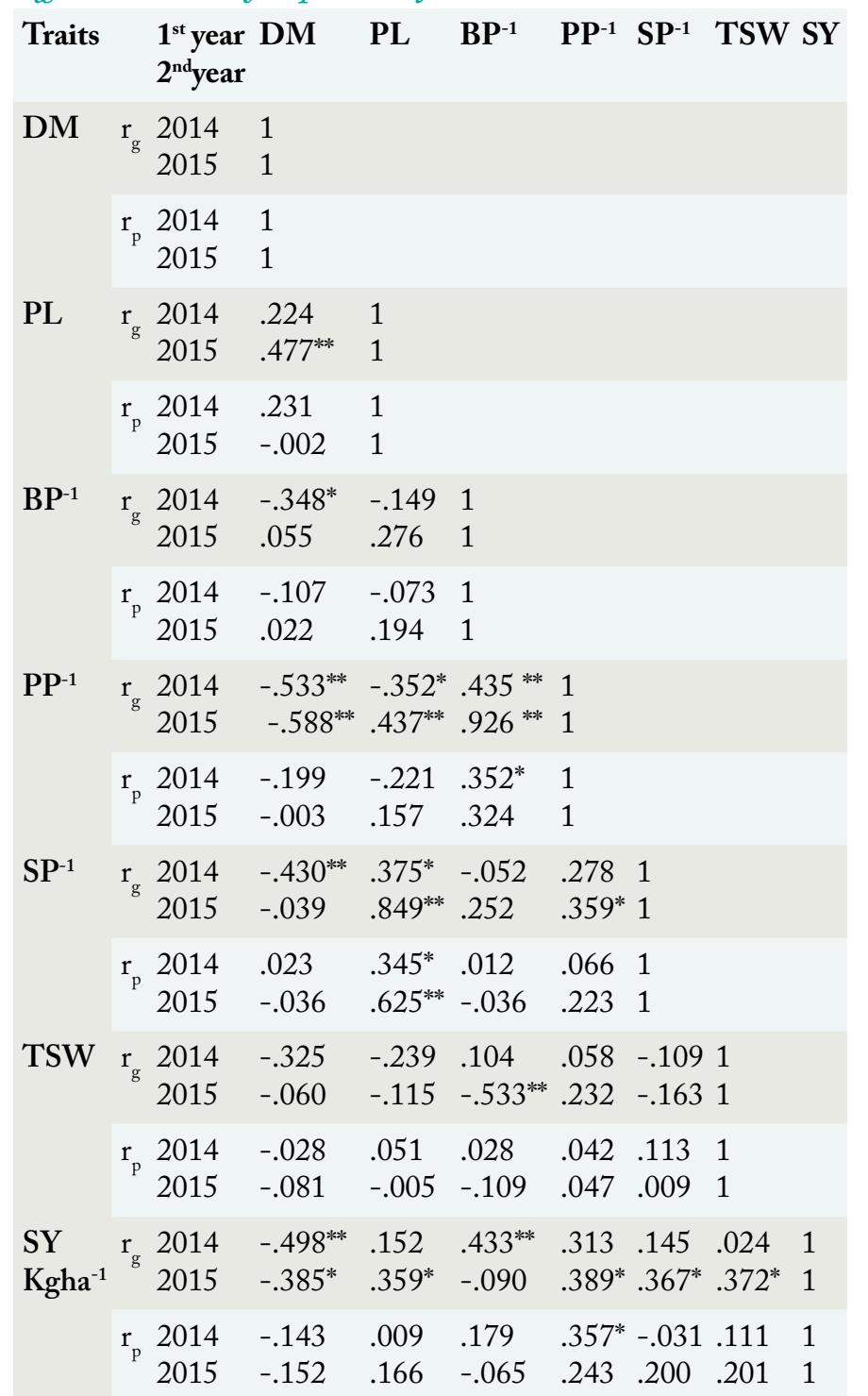

were recommended for further test under diverse environment and selected as desirable genotypes.

\section{Correlation analysis}

The degree and direction of association between two or more variables can be calculated from correlation coefficient. In this investigation both genotypic and phenotypic correlations were determined. Genotypic correlation coefficients were mostly higher than their particular phenotypic ones (Table 6). This indicated that these traits were associated genetically and the phenotypic expression of these traits was less influenced by the environment. In some cases the different signs of phenotypic and genotypic correlation coefficients indicated that the association was in the different direction. The results of both genotypic and phenotypic correlation are discussed as below.

During 2014: Days to maturity had negative and significant correlation with branches per plant ( $\mathrm{rp}=-$ $\left.0.1071 \mathrm{rg}=-0.3483^{*}\right)$, number of pods per plant ( $\mathrm{rp}$ $\left.=-0.1994 \mathrm{rg}=-0.5326^{* *}\right)$, seed yield $(\mathrm{rp}=-0.2155$ $\left.\mathrm{rg}=-0.1 .4514^{* *}\right)$ but its association with pod length was positive ( $\mathrm{rp}=0.2312 \mathrm{rg}=0.2236)$. Pod length had negative and significant correlations with pods per plant ( $\mathrm{rp}=-0.2155 \mathrm{rg}=-0.1 .4514^{* *}$ ) but positively correlated with seeds per pod $\left(\mathrm{rp}=0.399^{*} \mathrm{rg}=\right.$ $\left.0.3748^{*}\right)$ and seed yield $(\mathrm{rp}=0.0094 \mathrm{rg}=0.1524)$. The correlation of branches per plant with pods per plant $\left(\mathrm{rp}=0.3519^{* *}, \mathrm{rg}=0.4353^{* *}\right)$ and seed yield $\mathrm{kg} /$ ha $(\mathrm{rp}=0.1788 \mathrm{rg}=0.4329)$ was positive. Pods per plant exhibited positive correlation with seeds per 
pod ( $\mathrm{rp}=0.0656 \mathrm{rg}=0.2776), 1000$ seed weight ( $\mathrm{rp}$ $=0.0415 \mathrm{rg}=0.0582)$ and seed yield $(\mathrm{rp}=0.3574$

* rg $=0.3125)$. The genotypic correlation between number of seeds per pod was positive $(0.1446)$ but its phenotypic correlation was negative (-.0305). The association between seed weight and seed yield was also positive $\left(r_{p}=0.111 r_{g}=0.024\right)$.

\section{Table 7: Path coefficient of seed yield.}

\section{Path way of association}

$1^{\text {st }}$ year $2^{\text {nd }}$ Year Average

Yield vs. days to maturity

$\begin{array}{llll}\text { Direct effect } & -1.084 & -0.784 & -0.934 \\ \text { Indirect effect via pod length } & 0.107 & 0.829 & 0.468 \\ \text { Indirect effect via branches per plant } & -0.032 & -0.013 & -0.023 \\ \text { Indirect effect via pods per plant } & -0.168 & -0.542 & -0.355 \\ \text { Indirect effect via seeds per pod } & 0.323 & 0.016 & 0.170 \\ \text { Indirect effect via seed weight } & 0.121 & -0.010 & 0.056 \\ \text { Total correlation } & -0.808 & -0.036 & -0.422\end{array}$

Yield vs. pod length

$\begin{array}{llll}\text { Direct effect } & 0.478 & 1.739 & 1.109 \\ \text { Indirect effect via branches per plant } & -0.014 & -0.067 & -0.041 \\ \text { Indirect effect via pods per plant } & -0.111 & 0.403 & 0.146 \\ \text { Indirect effect via seeds per pod } & -0.281 & -0.353 & -0.317 \\ \text { Indirect effect via seed weight } & 0.089 & -0.019 & 0.035 \\ \text { Total correlation } & 0.229 & 0.953 & 0.591\end{array}$

Yield vs. branches per plant

$\begin{array}{llll}\text { Direct effect } & 0.092 & -0.243 & -0.076 \\ \text { Indirect effect via pods per plant } & 0.138 & 0.854 & 0.496 \\ \text { Indirect effect via seeds per pod } & 0.039 & -0.105 & -0.033 \\ \text { Indirect effect via seed weight } & -0.039 & -0.089 & -0.064 \\ \text { Total correlation } & 0.055 & -0.591 & -0.268 \\ \text { Yield vs. pods per plant } & & & \\ \text { Direct effect } & 0.316 & 0.922 & 0.619 \\ \text { Indirect effect via seeds per pod } & -0.208 & 0-.149 & -0.208 \\ \text { Indirect effect via seed weight } & -0.022 & 0.039 & 0.009 \\ \text { Total correlation } & 0.025 & -0.615 & -0.295 \\ \text { Yield vs. seeds per pod } & & & \\ \text { Direct effect } & -0.751 & -0.416 & -0.584 \\ \text { Indirect effect via seed weight } & 0.040 & -0.027 & 0.007 \\ \text { Total correlation } & -0.647 & -1.470 & -1.058 \\ \text { Yield vs. seed weight } & & & \\ \text { Direct effect } & -0.373 & 0.168 & -0.103 \\ \text { Total correlation } & -0.209 & 0.054 & -0.078\end{array}$

During 2015: A strong and significant association was observed between pod length and seed per pod $\left(\mathrm{rp}=0.6247^{* *}, \mathrm{rg}=0.849^{* *}\right)$. Pods per plant had positive and significant correlation with seeds per pod $\left(\mathrm{rp}=0.2233, \mathrm{rg}=0.3587^{*}\right)$. Similarly pods per plant exhibited positive and highly significant genotypic correlation with branches per plant and pod length (0.4373 and 0.926 respectively). Seed yield showed positive correlation with pod length $\left(\mathrm{rp}=0.166^{* *}, \mathrm{rg}\right.$ $\left.=0.3592^{*}\right)$, pods per plant $\left(\mathrm{rp}=0.2434, \mathrm{rg}=0.3889^{*}\right)$, number of seeds per pod $\left(\mathrm{rp}=0.200, \mathrm{rg}=0.3666^{*}\right)$, and seed weight $\left(\mathrm{rp}=0.2005, \mathrm{rg}=0.3718^{*}\right)$.Almost similar findings were reported by Ejaz-ul-Hasan et al., 2014 and Khan et al. (2005).

Days to maturity had negative and significant relationship with pods per plant $(\mathrm{rp}=-0.0027 \mathrm{rg}=$ $\left.-0.588^{*}\right)$ and seed yield ( $\left.\mathrm{rp}=-0.1518 \mathrm{rg}=-0.385^{*}\right)$. The association between branches per plant and seed weight was negative ( $\left.\mathrm{rp}=-0.1092 \mathrm{rg}=-0.5332^{* *}\right)$. This showed that the seed weight decreases when the branches per plant increases.

\section{Path coefficient}

The path analysis give the cause and effect of different yield components and provide better index for selection rather than mere correlation coefficients. The two years result of path analysis indicated that the direct effects of pod length and number of pods per plant were not only positive but also of high magnitude on seed yield. While the total correlation coefficients of seed yield with pod length was positive and of intermediate value (Table 7). So, direct selection for higher number of pods per plant and pod length would be effective to increase seed yield. Tusar-Patra et al. (2006) also observed that pods per plant had the strongest effect on seed yield. Days to maturity, branches per plant and seeds per pod had negative direct effect on seed yield. However, days to maturity had positive indirect effects via pod length (0.468), seeds per pod (0.170), and seed weight (0.056) with seed yield. Except pods per plant all the other traits via branches per plant exerted negative indirect effects on seed yield. Seeds per pod exerted positive indirect effect via seed weight (0.007).

\section{Conclusions}

Cluster analysis showed presence of considerable genetic variation among rapeseed hybrids studied. Correlation and path analysis revealed that the trait pods per plant had the maximum potential of selection for seed yield improvement because it exhibited highly significant positive correlation and maximum positive direct effects with seed yield.

\section{Author's Contribution}

Tahira conceived teh idea, collected data, wrote the 
manuscript and overall managed the research work. Muhammad Arshad and Mubashar Ahmad Khan did SPSS analysis. Muhammad Arshad helped in manuscirpt writing. Mubashar Ahmad Khan and Muhammad Ayub Khan provided technical input.

\section{References}

Ali, N. Javidfar, F. and Attary A.A. 2002.Genetic variability, correlation and path analysis of yield and its components in winter rapeseed (Brassica napusL.). Pak. J. Bot. 34 :145-150.

Arshad, M., Ilyas, M.K. and Khan, M.A. 2007. Genetic divergence and path coefficient analysis for seed yield traits in sunflower (Helianthus annuusL.) hybrids, Pak. J. Bot. 39: 2009-2015.

Burton, G.W. 1952. Quantitative inheritance in grasses. Proc. $6^{\text {th }}$ Int. Grassland Congress, 1: 277-283.

Dewey, D.R. and Lu, R.H. 1959. A correlation and path coefficient analysis of components of crested wheat grass seed production. Agron. J. 51: 515- 518. https://doi.org/10.2134/agronj19 59.00021962005100090002x

Ejaz-ul-Hasan, Mustafa, H.S.B. Bibi, T. and Mahmood, T. 2014. Genetic variability, correlation and path analysis in advanced lines of rapeseed (Brassica napusL.) for yield components. Cerelari Agronomice in Moldova. Vol. XLVII, No.1 (157):71-79.

Hasan,M.Seyis, F. Badani,A.G.Pons-Kühnemann, J. Friedt, W. Lühs, W. Snowdon, R.J. 2006. Analysis of genetic diversity in the Brassica napus L. gene pool using SSR markers. Genet. Resour. Crop Evol. 53: 793-802. https://doi. org/10.1007/s10722-004-5541-2

Lekh, R., Hari, S., Singh, V.P., Raj, L. Singh, H. 1998. Variability studies in rapeseed and mustard. Ann. Agric. Res. 19(1):87-88.

Marjanovic, J.A., Marinkovic, R., Ivanovska, S., Jankulovska, M,. Mijic, A. and Hristov N. 2011. Variability of yield determining components in winter rapeseed (Brassica napus L.) and their correlation with seed yield .Genetika. 43 (1):51-66. https://doi.org/10.2298/ GENSR1101051M

Khubli, S.K. and Pant, D.P. 1999. Correlation and path coefficient analysis of yield and its components in Indian mustard. Crop Res. Hisar. 17:371- 375.

Korkut, Z.K. Başer, İ. and Bilir, S. 1993. The studies path coefficient and correlation of drum wheat's. Symposium of Durum Wheat and Its Products, Ankara. 183-187.

Kwon, S.H. and Torrie, J.H. 1964. Heritability and interrelationship among traits of two soybean population. Crop Sci. 4: 196-198. https://doi.org/10.2135/ cropsci1964.0011183X000400020023x

Khan,M.H.Ali,M.M.Vhuiyan, S.R. and Mahmud, F. 2013. Genetic divergence in rapeseedmustard Brassica rapa L. Bangladesh J. Agric. Res. 38(3): 417-423. https://doi.org/10.3329/ bjar.v38i3.16968

Khan, F.A. Younas, M. and Mustafa, G. 2005. Correlation and factor wise contribution of the characters related to yield and quality of Brassica juncea L. Int. J. Agric. Biol. 7 (2): 257-259.

Mohan, G.S. and Seetharam, A. 2005. Genetic divergence in lines of sunflower derived from inter specific hybridization, SABRAO. J. Breed Gen.37: 77-84.

Tusar, P. Maiti, S. and Mitra, B. 2006.Variability correlation and path analysis of the yield attributing characters of mustard (Brassica spp.)," Res. Crops. 7(1): 191-193.

Punitha, B. Vindhiyavarman, P. and Manivannan, N. 2010. Genetic divergence study in sunflower (Helianthus annuus L.). Electron. J. Plant Breed, 1(4): 426-430.

Sandhu, S.K. and Gupta, V.P. 1996. Genetic divergence and correlation studies in Brassica Species. Crop Improv. 23: 253-256.

Shah, A.H. Gilani, M.M and Khan, F.A. 2000. Comprehensive selection of yield and yield influencing characters in Brassica species. Int. J. Agri. Biol. 2(3):245-247.

Seyedmohammadi, S.A. 2013. Evaluate correlation and path coefficient analysis for agronomic traits on grain yield of canola (Brassica napus L.) genotypes. Sci. J. Agron. Plant Breed. 1(1): 52-59.

Sneath, P.H.A. and Sokal, R.R. 1973. Numerical Taxonomy: The principles and practice of numerical classification. W.F. Freeman and Co., San Franciso. pp. 573.

Tuncturk, M. and Çiftçi, V. 2007. Relationships between yield and some yield components in rapeseed (Brassica napus ssp. oleifera L.) cultivars by using correlation and path analysis. Pak. J. Bot. 39 (1): 81-84. 